\title{
Academic Integrity and Religiosity
}

\author{
$1^{\text {st }}$ Hana Lailia Saadah* \\ Departement of Psychology Faculty of \\ Social Science and Humanity \\ UIN Sunan Kalijaga Yogyakarta \\ hanalailia28@gmail.com
}

\author{
$2^{\text {nd }}$ Lisnawati \\ Departement of Psychology Faculty of \\ Social Science and Humanity \\ UIN Sunan Kalijaga Yogyakarta \\ lisna_wt@ymail.com
}

\author{
$3^{\text {rd }}$ Kartika \\ Departement of Psychology Faculty of \\ Social Science and Humanity \\ UIN Sunan Kalijaga Yogyakarta \\ Kartikapsi47@gmail.com
}

\begin{abstract}
Academic integrity gives important contribution in developing high quality of education. One of important factors that contribute to academic integrity is religion, with religiosity as the expression of religion implementation. This present research focused on examining correlation between religiosity and academic integrity in students of SMK " $X$ " Magelang. One hundred grade X, XI and XII boarding school students were participated in this research. Purposive sampling was used as sampling technique. The correlation between variables was measured by Academic Integrity Scale and Religiosity Scale. Result of Spearman Rho technique analysis showed that there was a significant positive correlation between academic integrity and religiousity, with correlation coefficient $r_{x y}=0,526$, and $p<0,000$. This means that the higher level of subject religiosityshows the higher level of subjects academic integrity. Result of analysis also showed the effective contribution of religiosity, that was $27,7 \%$. Thus, there were other variables contribute to academic integrity such as age, gender, education, intelligence, ethnicity, and so forth.
\end{abstract}

Keywords — academic integrity, religiosity, students, high school

\section{INTRODUCTION}

Education has an important role in developing people to be intellectually intelligent. At the same time, education builds honest character, good self-control, being responsible, and benefiting the environment in which they live. These characters are summarized as academic integrity. Ronokusumo $^{[1]}$ said that the five important principles of academic integrity are honesty, mutual trust, openness, mutual respect, and a sense of responsibility.

According to International Center for Academic Integrity, academic integrity is an important element in the administration of national education ${ }^{[2]}$. Academic integrity is a commitment about positive values to create a good academical situation that make capable to act and behave in appropriate way ${ }^{[3]}$. Academic integrity is necessary built in the informal education learning process. Hopefully, the educational system not only concerns in student's academic achievement but also in developing and increasing morality and mentality.

There have been many cases about academic integrity violations that occured in Indonesia. One of the cases was in Senior High School of Indramayu that many students cheated in the mid of national examination. This academic dishonesty taken place when they did mathematics test. In the middle of the test, students used an answer key and passed it to one and another. This action happened due to the lack of time and understanding about the material ${ }^{[4]}$. Other data indicated by the result of a survey conducted to 20.000 Senior High School students showed that $80 \%$ of them ever cheat in a school project, two-thirds of them ever cheat in a test, and $90 \%$ of them ever copy homework ${ }^{[5]}$.

Inadequacy of student's academic integrity will cause dishonesty and cheating behavior in the future ${ }^{[6]}$. Moreover, violation of academic integrity that happened in school as plagiarism, dishonesty, and cheating will disturb student's learning process ${ }^{[7]}$. Recent issues about cheating in academic situations are the form of academic integrity violations.

As the result of pre-eliminary study which was conducted by researcher in SMK "X" Magelang, we found that the participants have less academic integrity violations. But, researcher also found through interviewing process to the teachers, that 2 of 4 students not doing homework before the lesson begins. This finding showed that there were students who had academic dishonesty. They did not have the responsibility on their homework.

There are some factors that affect the academic integrity such as age, gender, education, academic participation, academic achievement, ethnicity, intelligence, school policy, technology, academic integrity culture, social norms, influence of friends, and the severity of penalty that are given at school ${ }^{[8]}$. Rahmawati ${ }^{[8]}$ explains in his research about the Tendency of Academic Integrity at Jakarta Senior High School Students, that religiosityis one of the factors that influence academic integrity.

SMK religiousity, " $\mathrm{X}$ " Magelang based on religious principal and they are trying to increase student's academic integrity by giving the students a moral and religion lesson. However, academic dishonesty is still existed nowadays. Why academic dishonesty is still happening even though the students were given the religion lesson from school?

Schools based on religion such as Madrasah Aliyah, Madrasah Salafiyah, and Islamic Boarding School ideally can make well-behaved students because the learning proces is based on religion. The students of SMK " $\mathrm{X}$ " Magelang should have better religiositythan another students at another school. SMK "X" Magelang has good educational system and regulations that can create appropriate environment for students, so that the students should obey the regulations and have better academic integrity than students from other schools. In fact, the students of SMK " $\mathrm{X}$ " Magelang eventually still do the academic integrity violations. Based 
on the description above, this research focused in religiosityas the factor corelated to the academic integrity, as Rahmawati $^{[8]}$ said.

Religiosityis defined as how broad the knowledge, how strong the belief, how much the implementation of the worship as well as the rules, and how deep the appreciation about what they believe ${ }^{[9]}$. This study focused in islamic school because they not only teach Islamic subjects but also other religious activities such as Dhuha prayer as habit, memorizing ayyah from Al-Qur'an, and growing habit of akhlaqul karimah that hopefully could create attitude students.

A school based on Islamic faith is a school that implements Islamic concepts based on Al-Qur'an and As Sunnah. The main purpose of a school based on Islamic faith are strengthen the student's belief and then influence their characters. Therefore, researchers were interesting to examine the relationship between religiosityand academic integrity, because the most important aspect that influence an integrity is religiousity.

\section{METHOD}

This study used quantitative method. A total of 100 students participated in this study. The participant was a tenth, eleventh, and twelfth grade students who live in boarding school. The purposive sampling technique was used to select participants. Purposive Sampling is a method that gathered samples by purposely choosing subject based on the knowledge about certain feature and characteristic that appear on the previous population ${ }^{[10]}$. The analysis technique used in this study is Spearman Rho. Spearman Rho is used to see a relationship between two variables. The reason researchers use this technique is because the data obtained by researchers has an abnormal distribution.

\section{RESULT AND DISCUSSION}

SMK "X" Magelang is a part of Mambaul Huda foundation that located in Mambaul Huda Islamic Boarding School, Kaliabu, Salaman, Magelang. The vision of SMK " $\mathrm{X}$ " Magelang is "Have firm in faith and noble character, surpass in science and technology and ready to be independent entrepreneur or work." The mission is: 1) Preserving and developing the good values of the Islamic Boarding School in order to strengthen humanity and morality in the society; 2) Able to mastering science and technology as an insoluble part of the development of Islamic religious knowledge; 3) Growing motivation to students about charity and work are the part of worshiping Allah SWT; 4) Establish a cooperation with the business and industrial fields to make an employment for students who are graduated from Al Huda Vocational High School Salaman; 5) Building participation with the surrounding community, student guardians, school committees, in order to develop the school.

The result of Spearman Rho technique analysis showed that there was a significant positive correlation between religiosity and academic integrity, with correlation coefficient rxy $=0,526$, and $p<0,000$. This means that, the higher level of students religiosity showed the higher level of subjects academic integrity. If the students have high religiousity, so that they will have high academic integrity. Otherwise, the lower religiositystudents have, the lower academic integrity they have. If the students have low religiousity, so that they will have low academic integrity. The result of analysis also showed the effective contribution of religiosityto academic integrity was $27,7 \%$.

Students who had high religiositycan be seen in good behavior, such as obey all commandments of God, has an honest attitude with others, helping each other and when experiencing the difficulties they will try to be patience. They also had good responsibilities to their task such as a home work. These behaviour will shows both at school also at dormitory. They tend to obey existing regulations, always diligently following activities recite the Quran, pray in congregation, and share with each other. So wherever the students are, they tend to obey the rules.

As the conclussion, the results of this research found that religiositywas the one factors that influences academic integrity. Corresponding to Rahmawati ${ }^{[8]}$, academic integrity is influenced by several factors, and one of them is religion. Nashori and Mucharam ${ }^{[9]}$ explains that religion is something natural in human life, while religiosity is how broad the knowledge, how strong the beliefs, how much the implementation of worship, the rules, and how deep the appreciation to the religion.

Many religiosity activities at Islamic Boarding Schools such as in SMK "X" Magelang, could increase the students's beliefs in God and applied the knowledge about moral and religion beliefs that has been given to them. As Ancok and Suroso ${ }^{[11]}$ explained that, basically aqidah is embedded since pre-birth. Aqidah will be well-maintained throughout a person's life which is fulfilled with sufficient knowledge of Tauhid.

\section{CONCLUSION}

Based on the results of this study, it can be concluded that there was a positive relationship between academic integrity and religiosityon students in SMK " $\mathrm{X}$ " Magelang. The result showed that there was a significant positive correlation between religiosity and academic integrity. The higher the religiosity of the SMK " $X$ " students, the higher the academic integrity of them. Otherwise, the lower the religiosity, the lower the academic integrity of these students. The effective contribution of religiosity to academic integrity is $27.7 \%$. It shows that there are other factors that more affect the academic integrity than religiosity such as age, gender, education, academic participation, academic achievement, ethnicity, intelligence, school policy, technology, academic integrity culture, social norms, influence of friends, and the severity of penalty that are given at school.

\section{SUGGESTION}

\section{For participant}

It is expected to regularly improve the self-religiosity. Although, the effective contribution of religiosity that 
influences academic integrity is only $27.7 \%$, the religiosity still has an impact to students's academic integrity level.

\section{For schools}

The results of this research are expected to give an insight to the school about the religiosity and the academic integrity of their students who participated in this research. Religiosity has a contribution or influence on the students's academic integrity.

\section{For further researchers}

For further researchers who are interested in academic integrity and religiosity should add more references about Islamic knowledge and consider about the other variables that influence academic integrity.

\section{REFERENCES}

[1] S. Ronokusumo. (2012). Integritas akademik: Sekedar kata atau nyata?. Jakarta : Badan Penerbit Fakultas Kedokteran Universitas Indonesia.

[2] T. Fishman. (2014). The fundamental values of academic integrity. ( $2^{\text {nd }}$ ed.). Clemson University: International Center for Academic Integrity.

[3] N. Keohane. (1999). The fundamental values of academic integrity. The center for academic integrity. Duke University. http://www.academicintegrity.org/icai/assets/FVproject.pdf

[4] Toiskandar. (2015, April 14). News: aksi saling contek warnai ujian nasional.

https://news.okezone.com/read/2015/04/14/65/1133852/aksisalingcomtek- warnai-ujian-nasional. Accessed: Oktober 30, 2018

[5] S. Saider, S. Novick, and J. Gomez. (2013). Cultivating the academic integrity of urban adolescents with ethical philosophy programming. Peadoby Journal of Education, 88 (2), 142-158.

[6] A. E. Biswas. (2014). Lessons in citizenship: Using collaboration in the classroom to build community, foster academic integrity, and model civic responsibility. Journal on Excellence in College Teaching, 25 (1), 9 -25.

[7] P. J. Boehm, M. Justice and S. Weeks. (2009). Promoting academic integrity higher education. the community collage enterprise, 15 (1), 45-61.

[8] E. Rahmawati. (2016). Kecenderungan integritas akademik siswa sekolah menengah atas. Skripsi, Universitas Pendidikan Indonesia. http://repository.upi.edu/25510/

[9] F. Nashori and R. D. Mucharam. (2002). Mengembangkan kreatifitas dalam perspektif psikologi islam. Yogyakarta: Menara Kudus.
[10] B. Prasetyo and L. M. Jannah. (2012). Metode penelitian kuantitatif: Teori dan aplikasi. Jakarta : PT. Raja Grafindo Persada.

[11] D. Ancok and F. N. Suroso. (2001). Psikologi islam: Solusi islam atas problem - problem psikologi. Yogyakarta : PustakaPelajar. 